\title{
Egészségpedagógiai tapasztalatok a gyermekek kézmosásának oktatásában; higiénés nevelés a világjárványban
}

\author{
Feith Helga Judit dr. ${ }^{1}$ - Lehotsky Ákos dr. ${ }^{2}$ - Gézsi András dr. ${ }^{3}$ \\ Lukács J. Ágnes dr. ${ }^{1}$ - Gradvohl Edina dr. ${ }^{1}$ - Falus András dr. ${ }^{4}$ \\ ${ }^{1}$ Semmelweis Egyetem, Egészségtudományi Kar, Társadalomtudományi Tanszék, Budapest \\ ${ }^{2}$ Országos Onkológiai Intézet, Higiénés Csoport, Budapest \\ ${ }^{3}$ Budapesti Músszaki és Gazdaságtudományi Egyetem, Méréstechnika és Információs Rendszerek Tanszék, \\ Budapest \\ ${ }^{4}$ Semmelweis Egyetem, Általános Orvostudományi Kar, Genetikai, Sejt- és Immunbiológiai Intézet, Budapest
}

\begin{abstract}
Manapság, a COVID-19-járvány közepette, a megfelelő kézmosás segít megelőzni vagy legalábbis lassítani a fertőző betegségek, például a SARS-CoV-2-fertőzés terjedését. A kézmosás rutinjának megfelelő oktatás multilaterális tevékenységet igényel, amely a fiatalok ismeretén, egészségmagatartásán, attitűdjein, tapasztalatain és motivációján alapul. A TANTUdSZ Ifjúsági Egészségnevelési Program kortársoktató pedagógiai és egészségtudományi egyetemi karok hallgatóival, valamint középiskolai kortárssegítőkkel és mintegy 3000, magyarországi óvodás, általános és középiskolás diák bevonásával valósult meg, különböző egészségfejlesztési területeken. A vizsgálatok egyik célja az oktatási program hatékonyságának értékelése érdekében a gyermekek kézhigiénés ismereteinek és készségeinek elemzése és összehasonlítása volt a beavatkozások előtt és után. A jelen közleményben ismertetett longitudinális felmérés alsó tagozatos tanulók ( $\mathrm{n}=165$ ) kézmosási készségének és attitűdváltozásainak rövid és hosszú távú változását értékeli három időpontban. A mérések önkitöltős, anonim kérdőívvel és kéziszkenner-technológiával (Semmelweis Scanner) készültek, mely utóbbi mérési eszköz a különböző kézterületek tisztaságát kvantitatív és digitális értékelésekkel detektálta. A beavatkozás eredményes volt mind rövid, mind hosszú távon a bemeneti (kezdeti) mérésekhez képest. Az eredmények azonban különbséget mutattak a gyakorlati készségek elsajátításának folyamatában. Jelentős előrelépés történt a kézmosás attitúdjének változásában. Az életkor-specifikus egészségfejlesztési oktatási programokban, különösen a gyermekpopulációban, hangsúlyt kell fektetni az elméleti, a gyakorlati ismeretek, valamint az egészségmagatartás hosszú távú megőrzésére is.
\end{abstract} Orv Hetil. 2021; 162(46): 1842-1847.

Kulcsszavak: egészségfejlesztés, kézhigiéné, járványprevenció, hatékonyság

\section{Education of hand hygiene in children during the pandemia}

Presently, in the midst of the COVID-19 pandemic, proper hand washing helps prevent or at least slow the spread of infectious diseases such as SARS-CoV-2 infection. Proper education in hand washing routines requires multilateral action based on young people's knowledge, health behaviors, attitudes, experiences, and motivations. The TANTUdSZ Youth Health Education Program was implemented with students of contemporary teaching faculties of pedagogical and health sciences as well as with secondary school peer helpers and with the involvement of about 3000 pre-school, primary and secondary school students in Hungary in various fields of health development. One of the aims of the studies was to analyze and compare children's hand hygiene knowledge and skills before and after the pedagogical interventions in order to evaluate the effectiveness of the educational program. The longitudinal survey described in this paper assesses the short- and long-term changes of primary school students' (from class 1 to 4 ; $\mathrm{n}=$ 165) hand washing skills and the attitudinal changes in their health behaviors at three time points. Measurements were performed using a self-completion, anonymous questionnaire and hand-held scanner technology (Semmelweis Scanner), the latter measuring device detecting the purity of different hand areas with quantitative and digital evaluations. The educational intervention was effective in both short and long term compared to input (initial) measurements. However, the results showed a difference in the process of acquiring practical skills. There has been a signifi- 
cant progress in changing attitudes to hand washing. Age-specific health promotion education programs, especially in the pediatric population, should also focus on the long-term preservation of theoretical, practical knowledge, and health behaviors.

Keywords: health promotion, hand hygiene, epidemic prevention, efficiency

Feith HJ, Lehotsky Á, Gézsi A, Lukács JÁ, Gradvohl E, Falus A. [Education of hand hygiene in children during the pandemia]. Orv Hetil. 2021; 162(46): 1842-1847.

(Beérkezett: 2021. augusztus 24.; elfogadva: 2021. szeptember 21.)

\section{Rövidítések}

$\mathrm{CI}=($ confidence interval) konfidenciaintervallum; COVID-19 $=($ coronavirus disease 2019) koronavírus-betegség 2019; ETT TUKEB = Egészségügyi Tudományos Tanács, Tudományos és Kutatásetikai Bizottság; SARS-CoV-2 = (severe acute respiratory syndrome coronavirus 2) súlyos akut légúti tünetegyüttest okozó koronavírus-2; TANTUdSZ-program = Tanulj, Tanitsd, Tudd! Ifjúsági Egészségnevelési Program

A 2020 februárjától számított mintegy 17 hónap elteltével még mindig messze vagyunk attól, hogy világszerte véget érjen a hullámokban visszatérő COVID-19-járvány. Minden nap több százezer új koronavírus-fertőzéses eset fordul elő; világszerte csaknem 191 millió beteg esett át a fertőzésen, ami mintegy 4,1 millió elhalálozáshoz (hazánkban 30000 feletti ez a szám) vezetett a kézirat benyújtásának idején $[1,2]$. A védőoltások mellett a higiéniai biztonsági intézkedések betartatása is döntô momentumnak számít a járvány terjedése szempontjából $[3,4]$. A körültekintő epidemiológiai elemzésen túlmenően az emberek a fertőzés csökkentése érdekében többféle óvintézkedést is alkalmazhatnak, ideértve a maszk viselését, a kézmosást, a megfelelő távolságtartást, a tömeges találkozók elkerülését, a köhögés illemtanának betartását és a sokak által használt tárgyi felületek rendszeres tisztítását.

A kézmosási higiénia hatékonyságának növelése a lakosság minden korosztályában a kórokozók terjedésének csökkentését eredményezi. Különösen a gyermekek esetében az ilyen típusú egészségügyi oktatás bizonyosan hosszabb távú garanciákat nyújt a jövőre nézve is. A viselkedéselméletek szerint a kézhigiénés szokások 9-10 éves kor előtt valószínúleg szilárdan megalapozódhatnak [5]. A megfelelő kézmosási módszerek erôsen támogatják a jelenlegi és más, eljövendő fertőző járványok terjedésének és invazivitásának lassítását $[6,7]$. Számos, a társadalom felé irányuló üzenetküldési megközelítés lehet eredményes, a gyermek profilaktikus védelmén túlmenően, a családi környezet védelmére is összpontosítva (például: „mosson kezet szülei és nagyszülei védelme érdekében”) [8]. A gyermekek a legkorábbi életkoruktól kezdve optimális célpontok az egészségnevelésben, mivel a szülők sok esetben alábecsüllhetik az egészséget támogató magatartást (például a kézmosást), ráadásul ezt követően gyermekeik pozitívan befolyásolhatják szüleik, környezetük egészségmagatartását is $[5,8]$.

A jelen közleményben egy speciális, a kézmosási eljárások elsajátítására alkalmas oktatási módszertannak - a kortársoktatásnak - az eredményeit mutatjuk be. A kortársoktatási modell alapelve szerint a fiatalabb korosztályokban a néhány évvel idősebb gyermekek és fiatalok vonzó, követendő „példaképként” szolgálhatnak a fiataloknak, és képesek a szakértői oktatók által felügyelt, hatékony oktatás biztosítására [9]. A közoktatási intézményekben sajnálatos módon gyakran figyelmen kívül hagyják a kézhigiénés beavatkozásokat, bár ezek a mindennapi egyszerú protokollok igen könnyen kipróbálhatók és megvalósíthatók [10]. Ez a tény különösen sajnálatos nemcsak az iskolai hiányzások [11, 12], hanem a COVID mellett az egyéb fertóző betegségek megelözése $[6,7]$ esetében is. Nemzetközi források ösztönzik a kézhigiéné bevonásának és fokozásának szükségességét az oktatásban [13].

Ebben a tanulmányban a szerzők a kézhigiénés kortársképzési program kutatási módszertanát vezették be kisiskolás tanulók számára. 4 és 8 órás kézhigiénés képzési programjukat a pedagógiai és egészségtudományi karok hallgatóival, középiskolai kortárssegítőkkel végezték $[9,10,14]$. A gyakorlatorientált, 24 tanórás kortársoktatói képzés (vagyis a képzők képzése) során a diákok komplex ismeretet szerezhettek a kézhigiéné, a kortársoktatás, a konfliktuskezelés, valamint az iskolai egészségfejlesztési program módszertanához kapcsolódóan [9, 10]. A kutatás során fluoreszcenciaalapú szúróvizsgálati eszközt alkalmaztak, kombinálva a kézmosási eljárás számítógépes értékelésével (Semmelweis Scanner). A fizikai méréseket új fejlesztésű kérdőívekkel végzett szociológiai értékeléssel egészítették ki [10].

\section{Anyagok és módszerek}

\section{Mintavétel és a minta mérete}

A kézhigiénés képzési program és kutatás célpopulációját általános iskolában tanuló, alsó tagozatos gyermekek alkották (6-11 évesek). A gyerekek 4, illetve 8 órás kézhigiénés iskolai prevenciós programban vettek részt, miután a szülők írásban beleegyeztek gyermekük prog- 
ramban való részvételébe. A 4 órás programban részt vevő gyermekeknek egy iskolai napon, egybefüggő 4 tanórában, míg a 8 órás programban részt vevóknek két külön iskolai napon (de három héten belül), 4-4 tanórában történt az interaktív, korosztály-specifikus programok megtartása, folyamatos tutorálás mellett, de a kortársoktatók által összeállított programelemekkel [15]. A második 4 tanórában új információt, gyakorlati készséget már nem szereztek a gyermekek, hanem ismételhették a korábban megszerzett tudást és készséget. 165 tanuló töltötte ki a kérdőíveket - 84, a kézhigiéné-programban részt vevő, illetve 81 olyan kontrollgyermek, akik ugyanabba az osztályba jártak, ahová a kézhigiénéprogramban részt vevő gyermekek -, három időpontban (bemenetkor, közvetlenül a kortársoktatási programot követően, illetve 3,5 hónappal később). A kézmosás mérése ugyancsak három időpontban történt, egy innovatív, utraviolafény-alapú képalkotási technológiával, a Semmelweis Scannerrel [14], azonban az objektív kutatási eredmények érdekében a kutatásban részt vevő kisdiákok csak a legutolsó méréskor láthatták a Semmelweis Scanner által készített felvételt a kézmosási technikájuk eredményességéről.

A kutatás a megfelelő beleegyező szülői nyilatkozatokat tartalmazó engedély (ETT TUKEB No. 182402/2017/EKU) alapján került kivitelezésre.

\section{Kutatási eszközök}

A jelen tanulmányban a két kutatási módszer eredményeit mutatjuk be: a kvantitatív kutatás újonnan kidolgozott és strukturált kérdőívvel [9], míg a kézmosást modellező kézmosás technikájának értékelése a Semmelweis Scanner segítségével történt [16].

Az önkitöltős kérdőívben különféle validált és nem validált felmérések egyes elemeinek használatára került sor, kiegészítve saját kérdésekkel és válaszskálákkal [9]. Bár a célpopuláció kérdőíve hat fódimenzióból állt, a jelen közleményben kizárólag a kézhigiénéhez kapcsolódó vélemények, attitüdök (a továbbiakban: attitűdök) eredményeit, azok változásait ismertetjük. Az alábbi - dichotom - változók vizsgálata történt meg kisiskolások körében (a gyermekek életkorából adódóan „egyetért/ nem ért egyet” választ adhattak a felmérésben részt vevők):

- Fontos, hogy már a gyermekek is egészségesen éljenek.

- Az alapvető, rendszeres napi tisztálkodás (fürdés, kézmosás, fogmosás) hozzájárul ahhoz, hogy ritkábban betegszünk meg.

- A rendszeres kézmosás nem fontos, mert valamennyi koszra szükségünk van az egészségünk megőrzése érdekében.

- Az ember nem sokat tehet egészségének megőrzéséért.

- Már csak azzal, ha alaposan megmosom a kezem, teszek valamit az egészségem megőrzéséért.
- Ha megfelelően tisztálkodunk, és vigyázunk a tisztaságra, azzal mások egészségét is óvjuk.

- Ha felnőtt leszek, nekem fontos lesz a megfelelő tisztaság és a tisztálkodás, hogy jó példát mutassak a gyermekeknek/gyerekeimnek.

- Az életemben az egyik legfontosabb dolog az egészségem.

- Sajnálom az időt az alapvető, rendszeres napi tisztálkodásra (fürdés, kézmosás, fogmosás).

A Semmelweis Scanner egy digitális eszköz, amely valós idejü mérésre és számítógépes számszerüsítésre alkalmas [16]. A digitális fényképezőgép egy speciális fertőtlenítővel (Ecolab-Hygiene Kft.), ultraibolya által megvilágított környezetben fényképet készít. A számítógép vizuális és numerikus eredményeket is szolgáltat a kézmosás minőségéről (a kéz hiányzó régióiról). A két kéz felületein $9+1$ régió osztására került sor, mind a tenyéren, mind a kéz hátulján. Az ujjak egy régiót képviselnek, az ujjak végei pedig egyedi régióban vannak.

\section{Statisztika}

Az adatok statisztikai elemzése az R statisztikai szoftvercsomaggal (R Foundation for Statistical Computing, Bécs, Ausztria; 3.6 .3 verzió) készült. A kézszkennelés hibapontszámainak, illetve a különböző időszakok közötti attitűdpontszámoknak a változását Student-féle t-teszt felhasználásával mértük. Az egy adott csoport tagjainak értékében bekövetkezett változások esetén egymintás t-tesztet, míg két csoport összehasonlításakor kétmintás t-tesztet alkalmaztunk. Minden esetben a p<0,05 számított szignifikáns különbségnek.

\section{Eredmények}

Az elméleti és a gyakorlati kézmosási oktatás hatékonyságát az 1. táblázat mutatja be.

Mind a 4 , mind a 8 órás oktatás a szkennelt hibapontszámok jelentős csökkenését eredményezte az intervenciós program után közvetlenül. A kézmosási hibapontszámok átlagos csökkenése a beavatkozás előtt és a 4 és 8 órás oktatás után 1,91 (95\% CI: 0,60-3,21, p = 0,0047) és 4,71 (95\% CI: 2,28-7,15, p<0,001) volt. Megállapítható, hogy a 8 órás tanítás ebben az életkorban hatékonyabbnak tûnik, mint a 4 órás tanítás, a hibapontszámok csökkenése közötti átlagos eltérés a 8 vs. 4 óra oktatás között 1,76 (95\% CI: 0,19-3,33, p = 0,03) volt.

A kézmosásoktatás tartósságát - további kézhigiénéoktatás nélkül - 3,5 hónap után teszteltük (2/A táblázat).

Eredményeink azt sugallják, hogy a 3,5 hónapos szünet után a -4 vagy 8 órás programban részt vevő - gyermekek különböző mértékben emlékeztek a helyes kézmosási technikákra. A hibapontszámok átlagos csökkenése az első mérés és az oktatás után 3,5 hónappal történt mérés között 6,16 (95\% CI: 2,99-9,33, p<0,001) volt a kézmosás oktatásában részt vevő összes gyermek 
1. táblázat | A kézmosás oktatásának hatékonysága $(\mathrm{n}=84)$

\begin{tabular}{lcc}
\hline Az intervenció hossza & $\begin{array}{c}\text { A kézmosási hibaérték } \\
\text { csökkenése }\end{array}$ & p-érték \\
\hline *4 óra után & 1,905 & 0,0047 \\
\hline *8 óra után & 4,714 & 0,0004 \\
\hline $\begin{array}{l}\text { * A } 4 \text { és } 8 \text { órás képzés közti } \\
\text { különbség }\end{array}$ & 1,759 & 0,0295 \\
\hline
\end{tabular}

*A kézmosási hibák csökkenése (azaz a kézhigiéniai érték javulása) 4 és 8 óra oktatás után.

**Az oktatási hatékonyságok összehasonlítása (azaz a kézhigiéniai érték javulása) 4 és 8 óra oktatás után.

2/A táblázat $\mid$ A kézmosási ismeretek felidézése 3,5 hónap után $(\mathrm{n}=84)$

\begin{tabular}{|c|c|c|}
\hline Intervallum & $\begin{array}{c}\text { A kézmosási } \\
\text { hibaérték csökkenése }\end{array}$ & p-Érték \\
\hline $\begin{array}{l}\text { A ( } 4 \text { vagy } 8 \text { órás) kézhigiéné- } \\
\text { oktatásban részesült gyermekek } \\
\text { teljesítménye a kiindulási } \\
\text { értékekhez képest }\end{array}$ & 6,16 & 0,0005 \\
\hline $\begin{array}{l}\text { A } 4 \text { órás kézhigiéné-oktatásban } \\
\text { részesült gyermekek teljesítménye } \\
\text { a kiindulási értékekhez képest }\end{array}$ & 4,4 & 0,0333 \\
\hline $\begin{array}{l}\text { A } 8 \text { órás kézhigiéné-oktatásban } \\
\text { részesült gyermekek teljesítménye } \\
\text { a kiindulási értékekhez képest }\end{array}$ & 8,8 & 0,0067 \\
\hline $\begin{array}{l}\text { A } 4 \text { órás kézhigiéné-oktatásban } \\
\text { részesült gyermekek teljesítménye } \\
\text { a } 8 \text { óráshoz képest }\end{array}$ & 4,4 vs. 8,8 & $\begin{array}{c}\text { NS } \\
(0,1769)\end{array}$ \\
\hline
\end{tabular}

NS = nem szignifikáns 2/B táblázat $\mid \begin{aligned} & \text { A kontrollok és a kézhigiéné-oktatás hatásának összehasonlító } \\ & \text { eredményei }(\mathrm{n}=165)\end{aligned}$

\begin{tabular}{|c|c|c|}
\hline Intervallum & $\begin{array}{l}\text { A kézmosási } \\
\text { hibaérték } \\
\text { csökkenése }\end{array}$ & p-érték \\
\hline $\begin{array}{l}\text { A korábban kézhigiéné-oktatásban nem } \\
\text { részesültek (kontrollok) teljesítménye } \\
\text { a saját kiindulási értékeikhez hasonlítva }\end{array}$ & 3,64 & 0,0156 \\
\hline $\begin{array}{l}\text { A korábban } 4 \text { órás kézhigiéné-oktatás- } \\
\text { ban részesült gyermekek teljesítménye } \\
\text { a kontrollokhoz képest }\end{array}$ & 4,4 vs. 3,64 & $\begin{array}{c}\text { NS } \\
(0,7467)\end{array}$ \\
\hline $\begin{array}{l}\text { A korábban } 8 \text { órás kézhigiéné-oktatás- } \\
\text { ban részesült gyermekek teljesítménye } \\
\text { a kontrollokhoz képest }\end{array}$ & 8,8 vs. 3,64 & $\begin{array}{c}\text { NS } \\
(0,0934)\end{array}$ \\
\hline $\begin{array}{l}\text { A korábban } 4 \text { órás kézhigiéné-oktatás- } \\
\text { ban részesült gyermekek teljesítménye } \\
\text { a mostani } 4 \text { órás oktatás utáni } \\
\text { teljesítményhez képest }\end{array}$ & 0,4286 & $\begin{array}{c}\text { NS } \\
(0,6441)\end{array}$ \\
\hline $\begin{array}{l}\text { A korábban } 8 \text { órás kézhigiéné-oktatás- } \\
\text { ban részesült gyermekek teljesítménye } \\
\text { a mostani } 8 \text { órás oktatás utáni } \\
\text { teljesítményhez képest }\end{array}$ & 1,111 & $\begin{array}{c}\text { NS } \\
(0,4234)\end{array}$ \\
\hline
\end{tabular}

NS = nem szignifikáns körében: 4,4 (95\% CI: $0,40-8,40, \mathrm{p}=0,033)$ a 4 órás oktatásban és $8,8(95 \%$ CI: 3,11-14,5, p = 0,007) a 8 órás oktatásban részesülő gyermekek esetében.

Meglepő, hogy 3,5 hónap elteltével azok a gyermekek is növelték kezdeti teljesítményüket, akik nem rendelkeztek korábbi és közvetlenül célzott kézmosási oktatással (kontrollok). Az első mérés és az oktatás után 3,5 hónappal történt mérés közötti hibaértékek átlagos csökkenése 3,64 (95\% CI: 0,75-6,53, p = 0,016) volt a kontrollgyermekek körében (2/B táblázat). Bár azok, akik korábban kézhigiéné-oktatásban részesültek, egyértelmúen jobban teljesítettek, a különbség nem éri el a szignifikanciaszintet. A kézhigiéné-oktatásban részesülő gyermekek és a kontrollgyermekek hibaarányának csökkenése közötti átlagos különbség 3,5 hónappal a beavatkozás után 2,52 (95\% CI: $-1,66-6,7, p=0,23)$ volt.

A gyermekek attitüdváltozásának mérése is megtörtént az intervenció előtt, illetve a 4 vagy 8 órás kézhigiéné-programot követő 3,5 hónappal később (3. táblázat).

A szemléletbeli változást úgy számítottuk ki, hogy egy adott idôpontban (például 3,5 hónap után) rögzített kérdőív alapján kivontuk a bemeneti (beavatkozás előtt rögzített) attitűdök összesített pontszámát az összesített látogatott pontszámból. Így ennek pozitív jele azt jelenti, hogy a hozzáállás pozitívan változott.

Négy hónappal az oktatás után (4 vagy 8 órától függetlenül) a gyermekek kézhigiénével kapcsolatos attitúdpontszáma jelentősen megemelkedett. Az átlagos szemléletváltozás az első mérés (beavatkozás) és az oktatás után 3,5 hónappal végzett mérés között 1,12 (95\% CI: $0,45-1,79, \mathrm{p}=0,001)$ volt a kézmosás oktatásában részt vevő összes gyermek körében: 1,03 (95\% CI: 0,14-1,92, $\mathrm{p}=0,025)$ a 4 órás oktatásban és 1,29 (95\% CI: 0,22$2,36, p=0,021)$ a 8 órás oktatásban részesülő gyermekek esetében. Azok a kisdiákok, akik 8 orás oktatásban vettek részt, nagyobb szemléletváltást mutattak, összehasonlítva a 4 órás programban részt vevőkkel. Amint azt korábban bemutattuk, bár a kontrollgyermekek kézmosási teljesítménye nőtt, attitűdpontszámuk nem változott szignifikánsan (az átlagos szemléletváltozás az első mérés és az oktatás után 3,5 hónappal végzett mérés között 0,19 (95\% CI: $-0,57-0,95, \mathrm{p}=0,616)$ volt.

3. táblázat | Attitűdváltozások 3,5 hónappal az intervenció után $(\mathrm{n}=84)$

\begin{tabular}{lcc}
\hline Az intervenció hossza & $\begin{array}{c}\text { A hibaérték } \\
\text { csökkenése }\end{array}$ & p-érték \\
\hline $\begin{array}{l}\text { A } 4 \text { vagy } 8 \text { órás kézhigiéné-oktatásban } \\
\text { részesült gyermekek teljesítménye } \\
\text { a kiindulási értékeikhez képest }\end{array}$ & 1,119 & 0,0014 \\
\hline $\begin{array}{l}\text { A } 4 \text { órás kézhigiéné-oktatásban részesült } \\
\text { gyermekek teljesítménye a kiindulási } \\
\text { értékeikhez képest }\end{array}$ & 1,026 & 0,0249 \\
\hline $\begin{array}{l}\text { A } 8 \text { órás kézhigiéné-oktatásban részesült } \\
\text { gyermekek teljesítménye a kiindulási } \\
\text { értékeikhez képest }\end{array}$ & 1,286 & 0,0208 \\
\hline
\end{tabular}




\section{Megbeszélés}

A kézhigiénés magatartás a mindennapi emberi kultúra alapvető része. Nyilvánvaló, hogy fokozott figyelmet kap a COVID-19-járvány idején, és a jövőben várható járványok során is hangsúlyos lesz [17].

Hátrányos helyzetû́ társadalmi és regionális feltételek között, iskolai hiányzások következtében is [11, 12], a kézhigiéniai oktatás elmaradása kedvezőtlen módon befolyásolhatja a diákok egészségét, és fokozhatja a fertőzés terjedését. A szociológiai egészségnevelési tanulmányokat szigorúbban kell megtervezni, különös tekintettel a randomizálásra, a vakvizsgálatokra, a megvalósítás minőségére [18].

A kézhigiénés magatartás minden egészségnevelési stratégia fontos eleme. A jelen, hiánypótló pilotvizsgálat célja annak bemutatása volt, hogy a tanítás időtartama és ismétlései mennyiben befolyásolják a kézmosási eljárások tanításának eredményességét és hosszú távú hatásosságát a kisgyermekek (6-11 éves) körében.

A megfelelés (vagyis az egészségnevelési programban való együttmúködési hajlandóság) javítása érdekében az egyik legfontosabb cél az olyan objektív, elektronikus, számítógépes kiértékeléshez kapcsolható technológia használata, amely képes azonnali vizuális visszajelzésre a kézmosási eljárás hatékonyságáról. A megfelelő kézmosás kortársoktatási eljárásainak hatékonyságát sikerült objektív, tudományos módszerrel alátámasztani a kézmosási technika értékelésére kifejlesztett Semmelweis Scanner eszközzel [14]. Ezt az elektronikus eszközt tudomásunk szerint ez idáig nem alkalmazták a kézhigiéné iskolai oktatásában, miközben ezek az oktatási eszközök valós idejû mûszerek, amelyek azonnali megerősítést (és benyomást) nyújtanak a személynek (például kisdiáknak) a kézmosással kapcsolatban, és lehetővé teszik a már rögzült „rossz” szokások megváltoztatását. A kézmosási technika ellenőrzése és folyamatos tanítása ugyanolyan fontos a hatékonyság szempontjából, mint a helyes attitûd, a megfelelő motiváltság fenntartása.

A beavatkozás eredményeként a helyes válaszok aránya - az elméleti ismeretek [14], az attitüd és a gyakorlati készségek elsajátításának folyamatában jelentkező különbségek alapján - mind rövid, mind hosszú távon megnőtt a bemeneti mérésekhez képest. Érdekes, hogy hosszú távon még azok a gyermekek is (kontrollok), akik nem vettek részt közvetlen kézmosási oktatásban, növelték kezdeti teljesítményüket - ez vélhetően az osztálytárs gyermekek közötti társadalmi interakciók (szóbeli információátadás) miatt következett be [18-20], bár erre nem terjedt ki a kutatás. A másik fontos eredmény, hogy a kontrollgyermekek kézmosási teljesítménye nőtt, attitüdpontszámuk azonban nem változott jelentősen, miközben a pozitív hozzáállás, egészségmagatartás kialakítása valóban nélkülözhetetlen az egészségfejlesztési programokban.

$\mathrm{Az}$ eredmények szerint a kisgyermekek (6-11 éves) kézmosási technikájában már egy 4 órás beavatkozás is jelentős javulást idézhet elö, de hosszabb és/vagy emlékeztető, tudásfrissítő programokra van szükség ezen pozitív változások fenntartásához és megszilárdításához.

A jelen oktatási program másik fontos célja az objektív alapú, kvantitatív társadalomkutatási technikák kifejlesztése volt, ötvözve azokat hagyományos társadalomtudományi kutatási eszközökkel (kérdőíves felméréssel), mivel ezen a területen kihívást jelent megbízható és érvényes mérőeszközök alkalmazása a korábbi tudományos mérések alacsony száma és a bizonyítékokon alapuló egészségfejlesztési programok nehézségei miatt [18].

\section{Következtetés}

Kutatási tapasztalatainkra támaszkodva úgy gondoljuk, hogy a jól vizualizálható és számítógépes megoldások, kvantitatív társadalmi kutatási technikákkal, képesek kellőképpen értékelni a kézhigiénés tréningek hatékonyságát. A kézhigiénés program során mind az azonnali, mind az azt követő statisztikai elemzés segítségével bebizonyosodott, hogy az elektronikus készülék alkalmas a közvetlen visszacsatolásra. Úgy tünik, hogy ez a megközelítés akár növelheti a célpopuláció motivációját, és csökkentheti a kihagyott területek számát a következő kézmosás alkalmával, ez azonban már egy újabb kutatás témája lehet.

Anyagi támogatás: Magyar Tudományos Akadémia, Tantárgy-pedagógiai Kutatási Program (2007-2021).

Szerzői munkamegosztás: F. H. J.: A munka szervezése, a kérdőívek megalkotása és kiértékelése, a kézirat írása. L. A.: A Semmelweis Scanner bevezetése a munkába, az eredmények kiértékelése. G. A.: Bioinformatikai tevékenység. L. J. Á., G. E.: A kísérletek kivitelezése. F. A.: A projekt vezetése, a kézirat írása. A cikk végleges változatát valamennyi szerző elolvasta és jóváhagyta.

Érdekeltségek: A szerzőknek nincsenek érdekeltségeik.

\section{Köszönetnyilvánítás}

A kutatás a Magyar Tudományos Akadémia támogatásával, a Tantárgypedagógiai Kutatási Program keretein belül valósult meg. Külön köszönetet mondunk a HandInScan Zrt.-nek és az Ecolab-Hygiene Kft.nek a támogatásukért.

\section{Irodalom}

[1] Worldometer. COVID-19 coronavirus pandemic. Available from: https://www.worldometers.info/coronavirus/ [accessed: August 23, 2021].

[2] Johns Hopkins University \& Medicine, Coronavirus Resource Center. COVID-19 Dashboard by the Center for Systems Science and Engineering (CSSE) at John Hopkins University (JHU). Available from: https://coronavirus.jhu.edu/map.html [accessed: August 23, 2021]. 
[3] Cucinotta D, Vanelli M. WHO declares COVID-19 a Pandemic. Acta Biomed. 2020; 91: 157-160.

[4] Salzberger B, Buder F, Lampl B, et al. Epidemiology of SARS CoV-2. Internist 2020; 8: 782-788.

[5] Vermeil T, Peters A, Kilpatrick C, et al. Hand hygiene in hospitals: anatomy of a revolution. J Hosp Infect. 2019; 101: 383392.

[6] Aiello AE, Larson EL. Causal inference: the case of hygiene and health. Am J Infect Control 2020; 30: 503-511.

[7] Larson E. A causal link between handwashing and risk of infection? Examination of the evidence. Infect Control 1988; 9: 28 36.

[8] World Health Organization. \#HealthyAtHome - Healthy parenting. WHO, Geneva, 2020. Available from: https://www. who.int/campaigns/connecting-the-world-to-combat-coronavirus/healthyathome/healthyathome---healthy-parenting [accessed: August 23, 2021].

[9] Feith HJ, Lukács JÁ, Gradvohl E, et al. Health education - responsibility - changing attitude. A new pedagogical and methodological concept of peer education. Acta Univ Sapientiae Soc Anal. 2018; 8: 55-74

[10] Feith HJ, Lehotsky Á, Lukács JÁ, et al. Methodological approach to follow the effectiveness of a hand hygiene peer education training programme at Hungarian schools. Dev Health Sci. 2018; $1: 39-43$

[11] Wang Z, Lapinski M, Quilliam E, et al. The effect of hand-hygiene interventions on infectious disease-associated absenteeism in elementary schools: a systematic literature review. Am J Infect Control 2017; 45: 682-689.

[12] Willmott M, Nicholson A, Busse H, et al. Effectiveness of hand hygiene interventions in reducing illness absence among children in educational settings: a systematic review and meta-analysis. Arch Dis Child. 2016; 101: 42-50.

[13] Centers for Disease Control and Prevention. Handwashing: a family activity. CDC, Atlanta, GA, Sept 10, 2020. Available from: https://www.cdc.gov/handwashing/handwashing-family.html [accessed: August 23, 2021]
[14] Lehotsky Á, Falus A, Lukács Á, et al. Direct effect of contemporary health education programmes on the knowledge about hand hygiene and technique of hand washing in primary school age children. [Kortárs egészségfejlesztési programok közvetlen hatása alsó tagozatos gyermekek kézhigiénés tudására és megfeleló kézmosási technikájára.] Orv Hetil. 2018; 159: 485-490. [Hungarian]

[15] Lehotsky Á, Szilágyi L, Demeter-Iclănzan A, et al. Education of hand rubbing technique to prospective medical staff employing UV-based digital imaging technology. Acta Microbiol Immunol Hung. 2016; 63: 217-228.

[16] World Health Organization. WHO guidelines on hand hygiene in health care. WHO, Geneva, 15 Jan, 2009. Available from: https://www.who.int/publications/i/item/9789241597906 [accessed: August 23, 2021].

[17] Tolli MV. Effectiveness of peer education interventions for HIV prevention, adolescent pregnancy prevention and sexual health promotion for young people: a systematic review of European studies. Health Educ Res. 2012; 27: 904-913.

[18] Turner G, Shepherd J. A method in search of a theory: peer education and health promotion. Health Educ Res. 1999; 14: 235247.

[19] Bandura A. Social learning theory. Prentice Hall, Englewood Cliffs, NJ, 1977.

[20] Lukács ÁJ, Darvay S, Soósné Kiss Zs, et al. Health promotion among children and adolescents by peer education in the Hungarian and international literature - systematic review. [Kortárs egészségfejlesztési programok gyermekek és fiatalok körében a hazai és a nemzetközi szakirodalom tükrében: Szisztematikus áttekintés.] Egészségfejlesztés 2018; 59: 6-24. [Hungarian]

(Falus András dr., Budapest, Nagyvárad tér 4., 1089 e-mail: falus.andras@med.semmelweis-univ.hu)

\section{„Bármily fájdalmas, bármily nyomasztó is a beismerés, nem a letagadásban rejlik ellenszere." (Semmelweis Ignác)}

A cikk a Creative Commons Attribution 4.0 International License (https://creativecommons.org/licenses/by/4.0/) feltételei szerint publikált Open Access közlemény, melynek szellemében a cikk bármilyen médiumban szabadon felhasználható, megosztható és újraközölhető, feltéve, hogy az eredeti szerző és a közlés helye, illetve a CC License linkje és az esetlegesen végrehajtott módosítások feltüntetésre kerülnek. (SID_1) 